\title{
MENGELOLA DISRUPTION PADA INDUSTRI OTOMOTIF
}

Angelita Nauli Panggabean - 2301950881 - LB21

E-Business Strategy and Implementation

\begin{abstract}
Abstrak
Perkembangan teknologi dan kebutuhan untuk menemukan solusi yang berkelanjutan, industri otomotif telah mengalami perubahan atau momen inovasi. Sejumlah perusahaan baru menciptakan hal baru dalam industri, seperti kendaaraan mengemudi sendiri (self-driven) dan juga kendaraan listrik. Tujuan karya tulis ini adalah untuk melihat bagaimana gangguan atau disrupsi dapat dikelola. Dalam mencapai tujuan, penulis menggunakan metode tinjuan pustaka, dimana penulis mengumpulkan dan mempelajari jurnal-jurnal, baik internasional maupun nasional dari berbagai sumber di internet. Kesimpulan, secara singkat, disrupsi adalah dikelola dengan tiga langkah, antara lain Langkah pertama adalah memprediksi dampak model bisnis baru yang mengganggu, kedua memperkirakan berapa banyak konsumen yang dapat pindah ke produk baru, dan, langkah ketiga adalah memperluas analisis dampak model bisnis yang mengganggu ke sektor terkait lainnya.
\end{abstract}

\section{Kata Kunci: Disruption, Industri Otomotif}

\section{Pendahuluan}

Di tengah persaingan bisnis yang semakin ketat, perusahaan dituntut untuk menemukan strategi yang terbaik agar dapat bertahan (Hida Syahchari \& Amsal Sahban, 2019). Persaingan bisnis yang ketat ini disebabkan oleh kekuatan teknologi baru yang menggangu. Perkembangan teknologi telah mengubah fondasi hampir di setiap industri (Ferràs-Hernández et al., 2017). Ledakan kewirausahan dan startup digital mengeluarkan berbagai produk dan model bisnis yang menakjubkan yang dipicu oleh perubahan teknologi. Disrupsi tersebut hingga saat ini telah merambah ke industri oligopolistik, dimana dimoniasi oleh beberapa pemain besar yang membentuk industri otomotif. Menurut (Meyer et al., 2018), penggunaan teknologi ini akan menjadi solusi untuk jaringan industri otomotif yang lebih andal. Dengan bertambahnya kontribusi elektronik dalam konfigurasi teknologi mobil dan diiringi oleh kebutuhan, dinamika seluruh sektor menyaksikan perubahan paradigma (Ferràs-Hernández et al., 2017). Dengan kata lain, industri otomotif telah mengalami momen inovasi. Teknologi digital telah membuka pintu bagi industri untuk menaklukkan rantai nilai otomotif yang baru dan memunculkan model bisnis baru yang dibangun secara digital, intelligent algorithms, dan big data. Sejumlah perusahaan baru telah 
menyerbu industri otomotif dengan menawarkan desain baru, seperti kendaraan listrik, digital, dan self-driven. Era baru ini dimulai saat pemain lama melawan raksasa digital tersebut dan perusahaan baru mengendalikan teknologi masa depan. Dalam karya tulis ini, penulis bertujuan untuk melihat bagaimana gangguan atau disrupsi dapat dikelola. Untuk mencapai tujuan tersebut, penulis melakukan tinjauan pustaka yang berfokus pada bagaimana bagaimana gangguan atau disrupsi dapat di kelola.

\section{Tinjauan Pustaka}

Kata disrupsi sering dikaitkan dengan transformasi digital. Disrupsi mengungkapkan konsep bahwa perusahaan yang sukses sekali pun dapat gagal, meskipun terus melakukan apa yang mereka lakukan sebelumnya dengan baik (Candelo, 2019). Penelitian yang sudah dilakukan sebelumnya, menganalisis bagaimana suatu industri ditransformasikan oleh teknologi baru. Dalam kasus seperti itu, teknologi baru dikenalkan ke pasar dan menciptakan kehancuran kompetitif yang lama (Ferràs-Hernández et al., 2017). Pada industri otomotif, potensi terjadi gangguan dihasilkan oleh efek teknologi digital (Uber, Lyft, Gocar), mobil elektrik (Tesla), dan autonomous driving (Apple dan Google). Disrupsi dalam industri otomotif berasal dari perusahaan big data dan machine intelligence. Perusahaan atau seluruh sektor yang menjadi korban disrupsi belum tentu hilang. Mobil self-driving yang dipelopori oleh Google mungkin sudah biasa dan akan menjadi moda transportasi utama dalam dua-tiga dekade. Disrupsi didukung oleh gagasan bahwa perusahaan baru memenuhi kebutuhan pasar dengan produk, layanan, atau model bisnis, dimana karakteristik yang tidak dapat disediakan oleh perusahaan lama (Candelo, 2019).

Mengubah strategi menjadi cara yang lebih penting di lingkungan di mana teknologi berkembang pada tingkat yang eksponensial (Candelo, 2019). Beberapa perusahaan telah memperkirakan datangnya gangguan dan telah menginvestasikan sumber daya yang cukup besar untuk mengatasinya. Beberapa perusahaan lainnya hanya mengerti apa yang akan terjadi, yakni krisis keuangan. Berdasarkan (Gans, 2017), kunci untuk menangani gangguan adalah memahami bahwa itu muncul dikelilingi oleh ketidakpastian. Adapun faktor lain yang saling bergantungan, yaitu kapan dan bagaimana pembeli akan membuat keputusan mereka. Hal ini diperlukan untuk memulai dengan perilaku pelanggan dan harapan pelanggan. 


\section{Bagaimana Mengelola Gangguan}

Menurut Rogers (2016), langkah pertama saat menghadapi ancama disrupsi adalah memprediksi dampak model bisnis baru yang mengganggu terhadap perilaku konsumen. Langkah kedua adalah melibatkan penilaian kemungkinan penawaran dan memperkirakan berapa banyak konsumen yang dapat berpindah ke produk baru. Dalam industri otomotif, berapa banyak konsumen yang akan mengadopsi mobil tanpa pengemudi (mengingat harganya akan jauh lebih mahal daripada mobil tradisional). Langkah ketiga adalah memperluas analisis dampak model bisnis yang mengganggu ke industri lain yang terkait dengan industri yang diminati. Siapa pemain lama di industri lain yang akan terpengaruh, dan bagaimana reaksi mereka? Dalam kasus industri otomotif, analisis perlu diperluas ke rantai pasokan dan saluran distribusi. Namun, menurut Gans (2017), langkah ini sulit untuk diambil dan dapat memakan waktu karena biaya dan ketidakpastian. Ketidakpastian ini berasal dari fakta bahwa manajemen dapat mendeteksi ancaman produk atau layanan baru, tetapi ancaman ini belum tentu terbukti signifikan. CEO Renault-Nissan, Ghosn, menyatakan bahwa ketakutan akan gangguan industri otomotif berkaitan dengan kecepatan transformasi digital yang cepat.

\section{Metode}

Dalam penulisan karya tulis ini, metode yang digunakan penulis adalah metode tinjuan pusaaka. Tinjaun pustaka merupakan tinjuan tertulis dari sumber-sumber lain tentang topik yang dipilih, yakni disruption management pada industri otomotif. Sumber yang tercakup dalam tinjuan adalah jurnal-jurnal ilmiah. Jurnal-junal tersebut terdiri dari jurnal, baik internasional maupun nasional dari tahun 2016 sampai 2021 yang didapatkan dari sumber di internet.

\section{Kesimpulan}

Perkembangan teknologi mengakibatkan dampak bagi banyak industri, salah satunya pada industri otomotif. Teknologi ini menciptakan gangguan atau disrupsi. Kata disrupsi, dalam arti aslinya, mengungkapkan konsep bahwa bahkan perusahaan yang sukses pun bisa gagal, meskipun terus melakukan apa yang mereka lakukan sebelumnya dengan baik. Pada industri otomotif, potensi gangguan dihasilkan oleh efek gabungan dari lebih banyak teknologi digital, platform (Uber, Lyft, Gocar), electromobility (Tesla), dan autonomous driving (Apple dan Google). Mengubah strategi menjadi penting dalam situasi lingkungan yang berubah ini. Kemudian, 
bagaimana gangguan dapat dikelola? Langkah pertama adalah memprediksi dampak model bisnis baru yang mengganggu terhadap perilaku konsumen. Yang kedua memperkirakan berapa banyak konsumen yang mungkin dapat berpindah ke produk baru. Dalam industri otomotif, misalnya, berapa banyak konsumen yang akan mengadopsi mobil tanpa pengemudi atau mobil listrik. Dan, langkah ketiga adalah memperluas analisis dampak model bisnis yang mengganggu ke sektor terkait lainnya.

\section{Reference:}

Candelo, E. (2019). Is Disruption Taking Apart the Carmakers' World? In International Series in Advanced Management Studies (pp. 117-129). Springer Nature. https://doi.org/10.1007/978-3-030-15999-3_15

Ferràs-Hernández, X., Tarrats-Pons, E., \& Arimany-Serrat, N. (2017). Disruption in the Automotive Industry: A Cambrian Moment. Business Horizons, 60(6), 855-863. https://doi.org/10.1016/j.bushor.2017.07.011

Hida Syahchari, D., \& Amsal Sahban, M. (2019). The Impact of Intellectual Capital and Knowledge Management on Competitive Advantage. In International Journal of Innovation, Creativity and Change. www.ijicc.net (Vol. 10, Issue 8). www.ijicc.net

Meyer, A., Sejdovic, S., Glock, K., Bender, M., Kleiner, N., \& Riemer, D. (2018). A Disruption Management System for Automotive Inbound Networks: Concepts and Challenges. EURO Journal on Transportation and Logistics, 7(1), 25-56. https://doi.org/10.1007/s13676-0170108-5 